\title{
PROSES PELAKSANAAN KURSUS CALON PENGANTIN DI KANTOR URUSAN AGAMA KECAMATAN TAMALANREA DAN KECAMATAN BIRINGKANAYA
}

\author{
Zulkfli Wahab \\ Supardin \\ Patimah \\ Mahasiswa Pascasarjana UIN Alauddn Konsentrasi Syariah Hukum Islam \\ zulkifliwahab26@gmail.com
}

\begin{abstract}
Abstrak: tulisan ini mengkaji tentang pelaksanana Suscatin di KUA Tamalanrea dan KUA Biringkanaya. Penelitian ini menggunakan jenis penelitian (field research) kualitatif deskriptif. Lokasi penelitian berada pada dua (2) wilayah kecamatan di Kota Makassar yakni KUA Tamalanrea dan KUA Biringkanaya. Pendekatan penelitian yang digunakan adalah pendekatan teologis (syar'i), pendekatan yuridis formal, dan pendekatan sosiologis. Sumber data yakni Kepala Kantor Urusan Agama dan beberapa Pejabat dan Penyuluh Kantor Urusan Agama di Kecamatan Biringkanya dan Kecamatan Tamalanrea serta beberapa resopnden lainnya. Data dikumpulkan melalui observasi, wawancara, dan dokuementasi dengan instrumen pedoman observasi dan pedoman wawancara. Data diolah dengan reduksi data, penyajian data, dan penarikan kesimpulan.

Hasil penelitian menunjukkan bahwa proses penyelenggaraan kursus calon pengantin pada Kantor Urusan Agama Kecamatan Tamalanrea dan Biringkanaya Kota Makassar masih jauh dari target waktu yang diharapkan yaitu sekurang-kurangnya 16 jam pelajaran, semetara realisasinya hanya berkisar kurang lebih 2 jam, sehingga berpengaruh terhadap target materi yang ingin disampaikan. Dengan demikian proses pelaksanaan suscatin pada Kantor Urusan Agama di Kecamatan Tamaranrea dan Kecamatan Biringkanaya Kota Makassar terkesan hanya menjalankan peraturan tetapi mengabaikan apa yang sebenarnya yang menjadi esensi dari pelaksanaan suscatin tersebut. Suscatin atau bimbingan yang diberikan kepada calon pengantin merupakan dasar dari tujuan membangun keluarga yang harmonis.
\end{abstract}

\section{Keywords: Kursus Calon Pengantin, KUA Tamalanrea, KUA Biringkanaya}

\section{PENDAHULUAN}

Islam menganjurkan umatnya untuk melakukan perkawinan yang merupakan sarana yang sah dalam pembentukan keluarga. Perkawinan bukanlah semata sarana terhormat untuk mendapatkan anak yang saleh, untuk mengekang penglihatan, memelihara faraj atau hendak menyalurkan biologis, atau semata menyalurkan naluri saja. Akan tetapi lebih dari itu Islam memandang bahwa perkawinan sebagai salah satu jalan untuk merealisasikan tujuan yang lebih besar yang meliputi berbagai aspek kemasyarakatan berdasarkan Islam yang akan mempunyai pengaruh mendasar terhadap kaum muslimin dan eksistensi umat Islam. ${ }^{1}$ \footnotetext{
2013). h.38.

${ }^{1}$ Andi Syahraeni, Bimbingan Keluarga Sakinah (Cet, I; Makassar: Alauddin University Press,
} 
Membangun keluarga seperti halnya dalam menata kehidupan baru, tetapi sebaiknya kehidupan dilandasi dan berpedoman kepada al-Qur'an dan Hadis. Demi keselamatan dunia dan bekal untuk kehidupan di akhirat yang abadi serta menjadi pengetahuan kepada calon mempelai agar lebih memahami, mengerti, mengamalkan ajaran agamanya dengan baik dan benar untuk mencapai Baitiy Jannaty (rumahku adalah surgaku).

Setiap keluarga tentu mendambakan terwujudnya keluarga sakinah, mawaddah, warahma, yakni keluarga yang tenang, bahagia, harmonis, penuh cinta dan kasih sayang. Untuk mewujudkannya tidak semudah membalik telapak tangan, akan tetapi membutuhkan kerja sama yang baik. Keluarga seperti itu tidak mungkin akan tercapai tanpa adanya kebersamaan peranan seluruh keluarga di dalam rumah tangga. ${ }^{2}$

Kehidupan keluarga, apabila diibaratkan sebagai suatu bangunan, untuk terpeliharanya bangunan tersebut dari hantaman badai dan goncangan gempa, maka harus didirikan di atas pondasi yang kuat dengan bahan bangunan yang kokoh. Begitu juga halnya dengan membangun rumah tangga membutuhkan pondasi kekeluargaan yaitu ajaran agama Islam, disertai dengan kesiapan fisik dan mental calon ayah dan ibu. Disamping itu, perlu juga mengetahui hak dan kewajiban suami istri dan hal-hal yang berkaitan erat dengan hidup berkeluarga menurut ajaran Islam. ${ }^{3}$

Tujuan perkawinan adalah untuk memperoleh keluarga yang sakinah, mawadah dan rahmah. Tujuan perkawinan untuk memperoleh keluarga yang sakinah artinya tenang dalam hal, orang yang telah langsung melaksanakan perkawinan ingin memiliki keluarga yang tenang dan tentram. Tujuan perkawinan mawadah yaitu membentuk keluarga yang di dalamnya penuh dengan rasa cinta dan semua hal yg berkaitan dengan jasmaniah. Tujuan perkawinan rahmah yaitu memperoleh keluarga yang di dalamnya terdapat rasa kasih sayang, yakni yang berkaitan dengan hal-hal yang berkaitan dengan kerohanian.

Walaupun perkawinan memiliki tujuan yang mulia namun ikatan perkawinan tidak serta merta selalu berjalan mulus dan jalan yang terakhir yang ditempuh dua belah pihak yang terikat dalam perkawinan ketika merasa tidak mampu menemukan jalan keluar dengan berbagai alasan adalah pemutusan ikatan perkawinan. Padahal, perceraian merupakan sesuatu yang halal namun sangat dibenci oleh Allah swt.

Oleh karena itu, dalam Peraturan Direktur jenderal Bimas Islam Kementerian Agama Nomor: DJ.II/542 Tahun 20013, diinstruksikan agar sebelum perkawinan dilangsungkan, setiap calon pengantin harus diberikan wawasan terlebih dahulu tentang arti sebuah rumah tangga melalui kursus calon pengantin (suscatin) yang diadakan oleh Kantor Urusan Agama (KUA).

Oleh karena itu, berdasarkan Peraturan yang diterbitkan Direktur Jenderal Bimbingan Masyarakat Islam Kementerian Agama Nomor DJ.II/542 Tahun 2013 yang didalamnya terdapat Pedoman dan Petunjuk Teknis penyelenggaraan Kursus Pranikah untuk para calon pengantin.

Dalam buku pedoman tersebut, sepasang calon suami-isteri diberi informasi singkat tentang kemungkinan yang akan terjadi dalam rumah-tangga, sehingga pada

${ }^{2}$ Muhammad Saleh Ridwan, Keluarga Sakinah Mawadda Warahma (Cet, I; Makassar : Alauddin University Press, 2012). h.5.

${ }^{3}$ Rosmaniah Hamid, Hadis-Hadis Keluarga dan Sakinah dan Implementasinya dalam Pembentukan Masyarakat Madani (Cet, I; Makassar: Alauddin University Press,2011), h. 25. 
saatnya nanti dapat mengantisipasi dengan baik, paling tidak berusaha mewantiwanti jauh-jauh hari agar masalah yang timbul kemudian dapat diminimalisir dengan baik, untuk itu bagi remaja usia nikah atau catin (calon pengantin) sangat perlu mengikuti pembekalan dalam bentuk kursus pranikah dan yang merupakan salah satu upaya penting dan strategis. ${ }^{4}$

Kantor Urusan Agama (KUA) merupakan bagian institusi pemerintah yang bertugas memberikan pelayanan kepada masyarakat, khususnya di bidang urusan agama Islam. KUA memiliki badan resmi yang dibentuk hasil kerja sama dengan masya rakat antara lain: Badan Penasehatan, Pembinaan dan Pelestarian Perkawinan (BP4), Penyuluhan Pengalaman Ajaran Agama Islam (P2I).

Dengan demikian dapat di pahami bahwa sesungguhnya tujuan dari kursus calon pengantin adalah untuk meningkatkan pemahaman dan pengetahuan tentang kehidupan rumah tangga dalam mewujudkan keluarga yang harmonis serta mengurangi angka perselisihan, perceraian dan kekerasan rumah tangga. Oleh karena itu, tulisan ini mengkaji tentang pelaksanana Suscatin di KUA Tamalanrea dan KUA Biringkanaya.

\section{KAJIAN TEORETIS}

\section{A. Definisi Suscatin}

Pembinaan bagi calon pengantin merupakan suatu keabsahan perkawinan dari kepedulian pemerintah, hal ini sesuai dengan Peraturan Direktur Jenderal Bimbingan Masyarakat Islam Kepartemen Agama Nomor: DJ.II/542 Tahun 2013 tentang kursus calon pengantin. Salah satu isi butir peraturan tersebut pasal 1 ayat 2 adalah "kursus calon pengantin yang selanjutnya disebut dengan suscatin adalah pemberian bekal pengetahuan, pemahaman dan ketrampilan dalam waktu singkat kepada catin tentang kehidupan rumah tangga/keluarga." Kemudian pada bab IV bagian pertama penyelenggara pasal 4 ayat 1 disebutkan "penyelenggara kursus catin adalah Badan Penasihatan, Pembinaan dan Pelestarian Perkawinan (BP4) atau lembaga lain yang telah mendapat Akreditasi dari Departemen Agama." Maka dalam hal ini pemerintah sangat diharapkan memberi kontribusi yang lebih luas kepada masyarakat yang kurang memiliki bekal dalam menikah. ${ }^{5}$

Kualitas sebuah pernikahan sangan ditentukan oleh kesiapan dan kematangan kedua calon pengantin dalam menyongsong kehidupan rumah tangga, pernikahan sebagai peristiwa sakral dalam perjalan hidup dua individu yang berbeda dan banyak sekali harapan untuk kelanggengan suatu pernikahan, namun ditengah perjalan kandas dan berujung pada perpisahan karena kurangnya kesiapan dari kedua belah pihak dalam mengarungi bahterah rumah tangga. Agar harapan dalam membentuk rumah tangga bahagia dapat terwujud maka diperlukan pengenalan terlebih dahulu tentang kehidupan baru yang akan dijalani nantinya.

Dengan dikeluarkannya Peraturan Dirjen Bimas Islam No. DJ. II/542 Tahun 2013 membuat gerak suscatin sudah jelas. Lahirnya peraturan-peraturan tentang suscatin tersebut, merupakan bentuk kepedulian pemerintah terhadap tingginya angka perceraian dan kasus kekerasan dalam rumah tangga (KDRT)di Indonesia.

4 Kementerian Agama RI, Direktorat Jenderal Bimbingan Masyarakat Islam, Pedoman Penyelenggaraan Kursus Pra Nikah (Jakarta: Kementerian Agama RI, 2011), h. 14.

${ }^{5}$ Kementerian Agama RI, Direktorat Jenderal Bimbingan Masyarakat Islam, Pedoman Penyelenggaraan Kursus Pra Nikah, (Jakarta: Kementerian Agama RI, 2013), h. 538 
Pengetahuan mereka tentang dasar-dasar pernikahan masih sangat kurang. Sehingga pemerintah dalam hal ini kementerian Agama mengeluarkan peraturan tentang suscatin, yakni calon pengantin yang akan hendak melakukan pernikah akan lebih terdahulu dibimbing atau dibekali dengan materi-materi dasar pengetahuan dan keterampilan seputar kehidupan rumah tangga.

\section{B. Kurikulum dan Silabus Suscatin}

Penyelenggaan kursus calon pengantin telah diatur dalam Peraturan Direktur jenderal Bimbingan Masyarakat Islam Kementerian Agama tahun 2013. Dalam peraturan tersebut, yang dimaksud dengan kursus calon pengantin adalah pemberian bekal pengetahuan, pemahaman, keterampilan dan penumbuhan kesadaran kepada remaja usia nikah tentang kehidupan rumah tangga dan keluarga. Adapun materi yang menjadi pembahasan dalam kursus tersebut telah disusun dengan deskripsi silabus sebagai berikut:

A. Kelompok Dasar

Pada tahap ini, peserta diberi uraian awal atau pengantar tentang Kebijakankebijakan pemerintah tentang pembinaan keluarga sakinah dan pelaksanaan kursus calon pengantin. Adapun materi pokok yang berkaitan dengan undang-undang yang dipelajari oleh peserta ialah :

1) UU perkawinan dan Kompilasi Hukum Islam. Dalam peraturan ini, peserta diberikan uraian tentang:
a. Konsep perkawinan
b. Asas perkawinan
c. Pembatasan poligami
d. Batasan usia
e. Pembatalan perkawinan
f. Perjanjian perkawinan
g. Harta bersama
h. Hak dan kewajiban
i. Masalah status anak
j. Perkawinan campuran

2) UU KDRT. Adapun uraian materinya ialah:
a. Pengertian KDRT
b. Bentuk - bentuk KDRT
c. Faktor - faktor penyebab KDRT
d. Dampak KDRT
e. Aturan Hukum
f. Tanggung jawab pemerintah dan keluarga.

3) UU Perlindungan Anak. Adapun uraian materinya ialah:

a. Pengertian anak

b. Hak anak dan kedudukan anak dalam Islam

Selain aturan dari pemerintah dan undang-undang, peserta juga diberikan landasan hukum Islam tentang perkawinan (munakahàt). Adapun kompetensi yang ingin dicapai dari materi ini ialah agar peserta memahami ketentuan-ketentuan syariah tentang fikih munakahät. Dengan demikian, indikator yang terdapat dalam materi hukum munakahät ini ialah:

a. Menjelaskan konsep dasar perkawinan

b. Menjelaskan tujuan dan hikmah perkawinan 
c. Menjelaskan syarat dan rukun nikah

d. Menjelaskan akad nikah dan ijab Kabul

e. Menjelaskan hak dan kewajiban suami isteri

f. Menjelaskan mu'āsarah bil ma'rüf

g. Menjelaskan adab nikah

h. Menjelaskan hak dan kewajiiban orang tua terhadap anak

Setelah penjelasan mengenai landasan yuridis dan syariah mengenai perkawinan, sebagaimana yang tertera dalam peraturan, pemberi materi akan menjelaskan prosedur perkawinan.

B. Kelompok Inti

Pada tahap ini, peserta sudah memasuki uraian-uraian inti, yaitu hal-hal yang harus diketahui seputar kehidupan rumah tangga. Adapun mata diklat pada tahap ini antara lain:

1) Pelaksanaan fungsi - fungsi keluarga. Kompetensi yang ingin dicapai pada materi ini ialah:

a. Mampu memahami fungsi - fungsi keluarga

b. Mampu menjelaskan seecara kontekstual funsgi- fungsi keluarga dengan pengalaman kehidupan perkawinan dan keluarga

c. Mampu mengimplementasikan dalam kehiidupan keluarga melalui action plan.

Dalam mata diklat ini materi-materi yang harus dipelajari oleh peserta

berdasarkan kompetensi yang ingin dicapai ialah:

1. Fungsi agama, dengan uraian mteri sebagai berikut:

a. Memfungsikan nilai-nilai ajaran Islam dalam kehidupan rumah tangga

b. Fungsi pemeliharaan fitrah manusia

c. Penguatan tauhid dengan pengembangan akhläqul karimah.

2. Fungsi reproduksi, yaitu fungsi reproduksi yang didasarkan akad perkawinan yang sah

3. Fungsi kasih sayang dan afeksi, dengan uraian materi sebagai berikut:

a. Kasih sayang dan afeksi sebagai kebutuhan dasar manusia

b. Kedekatan dan kelekatan fisik dan batiniyah anak dan orang tua

c. Ketertarikan kepada lawan jenis sebagai sunnatullah

d. Kasih sayang sebagai landasan amal sholeh yang memberi manfaat bagi sesama.

4. Fungsi Perlindungan, dengan uraian metei sebagai berikut:

a. Hak dan kewajiban suami isteri memiliki fungsi perlindungan

b. Perlindungan terhadap anggota keluarga dari kekerasan dan pengabaian

c. Perlindungan terhadap tumbuh kembang anak

5. Fungsi pendidikan dan sosialisasi nilai, dengan uraian sebagai berikut:

a. Fungsi keluarga bagi pembentukan karakter

b. Fungsi sosialisasi dan transmisi nilai

c. Fungsi keteladanan dan modeling

d. Fungsi membangun benteng moralitas

6. Fungsi ekonomi

a. Fungsi produksi untuk memperoleh penghasilan 
b. Fungsi pembelanjaan untuk memenuhi kebutuhan bagi kelangsungan keluarga.

c. Keseimbangan antara income dan pengeluaran.

d. Diperlukan tata kelola keuangan dan keluarga

7. Fungsi Sosial Budaya

a. Keluarga sebagai unit terkecil dan inti dari masyarakat

b. Keluarga sebagai lingkungan sosial budaya terkecil.

c. Nilai-nilai keluarga mencerminkan nilai-nilai dalam masyarakat

d. Pengejawantahan nilai - nilai agama

2) Merawat cinta kasih dalam Keluarga. Dalam mata diklat ini, materi pokok yang dipelajari oleh peserta ialah:

a. Nilai-nilai dalam keluarga untuk mewujudkan mu'āsyarah bil ma'ruf, dengan uraian sebagai berikut:

1) Larangan menyia-nyiakan suami/ isteri

2) Cooling down

3) Menahan diri dan mencari solusi positif

b. Formula sukses dalam mengelola kehidupan perkawinan dan keluarga

c. Komunikasi efektif dalam pengelolaan hubungan keluarga, dengan uraian materi sebagai berikut:

1) Deskripsi komunikasi yang efektif

2) Komunikasi dalam keluarga

3) Komunikasi dalam kehidupan sehari - hari

4) Macam - macam komunikasi dalam keluarga

3) Manajemen konflik dalam keluarga. Pada mata diklat ini, materi pokok yang dipelajari ialah:

a. Faktor penyebab konflik, dengan uraian sebagai berikut:

1) Pebedaan kepentingan dan kebutuhan

2) Komunikasi tidak efektif

3) Hambatan penyesuaian diri

b. Tanda - tanda perkawinan dalam bahaya:

1). Cekcok terus menerus

2). Cara komunikasi yang merusak hubungan

c. Solusi atau cara mengatasi konflik :

1). Pasangan

2). Keluarga besar masing - masing pihak

3). Institusi konseling

4). Psikologi perkawinan dan keluarga, dengan materi pokok:

a. Pengertian / Deskripsi, dengan uraian tentang:

1) Pengertian psikologi perkawinan

2) Pengertian keluarga

3) Ruang lingkup psikologi keluarga

b. Upaya mencapai keluarga sakinah, yang akan menguraika tentang:

1) Membentuk akhlak luhur

2) Menegakkan rumah tangga Islami

3) Meningkatkan ibadah

c. Membina hubungan dalam keluarga, dengan uraian materi tentang: 
1) Harmonisasi suami-isteri

2) Orang tua dan anak

3) Anak dengan anak

4) Anak dan anggota keluarga lain

5) Kebersamaan dalam keluarga

C. Kelompok Penunjang

Pada tahap ini, peserta akan diberikan langkah tambahan untuk mempermantap pemahaman peserta yaitu dengan:

1. Pendekatan andragogi

2. Penyusuna SAP (Satuan Acara Pembelajaran) dan Micro Teaching

3. Pre Test dan Post Test

4. Penugasan / Action plan ${ }^{6}$

Berdasarkan Peraturan Direktur Jenderal Bimbingan Masyarakat Islam tahun

2013 tentang Penyelenggaraan Kursus Pranikah, Keseluruhan materi di atas disampaikan pada beberapa pertemuan yang dikondisikan dengan peserta dengan jumlah jam pelajaran sebanyak 16 jam atau dibuat beberapa kali pertemuan dengan jam pelajaran yang sama. Waktu pelaksanaannya dapat disesuaikan dengan kesempatan yang dimiliki oleh peserta. ${ }^{7}$

Pelaksanaan kursus calon pengantin di beberapa Negara ASEAN seperti Malaysia dan Singapura dilaksanakan oleh badan atau lembaga masyarakat dengan dukungan regulasi dari pemerintah. Majelis Ulama Islam Singapura (MUIS) merupakan contoh negara yang menyelenggarakan kursus pra nikah selama satu atau sampai tiga bulan dengan delapan kali pertemuan, sedangkan Jabatan Kemajuan Agama Islam Malaysia (JAKIM) melaksanakan kursus pranikah selama tiga bulan dengan 8 sampai 10 kali pertemuaan. Adapun waktu pelaksanaannya disesuaikan dengan waktu libur yang dimiliki oleh peserta kursus yang umumnya pegawai atau buruh. ${ }^{8}$

Bimbingan Perkawinan sebagai bantuan yang diberikan kepada individu, untuk mengembangkan kemampuan-kemampuan dengan baik agar individu ini dapat memecahkan masalahnya sendiri dan dapat mengadakan penyesuaian diri dengan baik. $^{9}$

Berangkat dari keterangan di atas dapat disimpulkan mengenai pemahaman kursus calon pengantin adalah sebagai bantuan yang diberikan kepada calon pasangan suami istri yang bisa berupa pengarahan, nasehat, petunjuk, tuntunan, dan pemberian informasi mengenai hak dan kewajibannya atau berbagai hal pengetahuan dalam rangka menambah wawasan tentang perkawinan, dengan tujuan agar pasangan tersebut mampu menyatukan perbedaan sehingga nantinya dapat membentuk keluarga yang harmonis. Sehingga dalam proses adaptasi usia awal pernikahan berjalan lancer,

\footnotetext{
${ }^{6}$ Kementerian Agama RI, Direktorat Jenderal Bimbingan Masyarakat Islam, Modul Pelatihan Motivator Keluarga Sakina,(Jakarta: Kementerian Agama RI, 2011) h. 7-12

${ }^{7}$ Kementerian Agama RI, Direktorat Jenderal Bimbingan Masyarakat Islam, Pedoman Penyelenggaraan Kursus Pra Nikah, h. 542

8 Kementerian Agama RI, Direktorat Jenderal Bimbingan Masyarakat Islam, Pedoman Penyelenggaraan Kursus Pra Nikah, h. 584

9 Bimo Wal Gito, Bimbingan dan Konseling Perkawinan (Yogyakarta: Yayasan Penerbit Fakultas Psikologi UGM, 1984), h. 5-7.
} 
artinya pasangan calon pengantin memang secara jelas dituntun untuk lebih dewasa dalam menyikapi setiap sisi dalam pernikahan. Baik itu persoalan materi, psikis dan biologis.

\section{Dasar Hukum Suscatin}

Dasar dari bimbingan perkawinan adalah al-Qur'an, Hadis, dan UndangUndang karena keduanya merupakan dasar hukum yang mengatur segala prilaku manusia untuk kebahagiaan hidup di dunia dan akhirat. Kedua dasar hukum tersebut di dalamnya mengandung ajaran yang bertujuan membimbing ke arah kebaikan dan menjauhkan dari kesesatan.

1) QS al- Tahrim/66:6

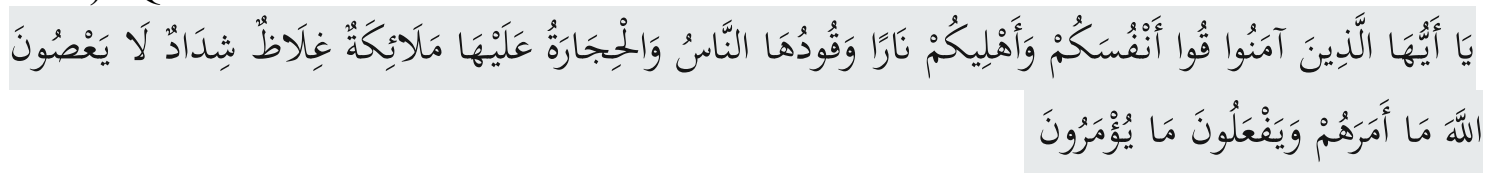

Terjemahnya:

"Hai orang-orang yang beriman, peliharalah dirimu dan keluargamu dari api neraka yang bahan bakarnya adalah manusia dan batu; penjaganya malaikatmalaikat yang kasar, keras, dan tidak mendurhakai Allah terhadap apa yang diperintahkan-Nya kepada mereka dan selalu mengerjakan apa yang diperintahkan." 10

Mengenai firman Allah swt., قُو أَنْفُكَكُمْ وَأَهْلِيكُمْ نَارَا "peliharalah dirimu dan keluargamu dari apa neraka", Qatadah mengemukakan: yakni, hendaklah engkau menyuruh mereka berbuat taat kepada Allah swt., dan mencegah mereka durhaka kepada-Nya. dan hendeklah engkau menjalankan perintah Allah kepada mereka dan perintahkan mereka untuk menjalankannya, serta membantu mereka dalam menjalankannya. Jika engkau melihat mereka berbuat maksiat kepada Allah peringatilah dan cegahlah.

Demikian itu pula yang dikemukakan oleh Adh Dhahhak dan Muqatil bin Hayya, dimana mereka mengatakan: setiap muslim berkewajiban mengajari kelauarganya, temasuk kerabat dan budaknya, berbagai hal berkenaan dengan hal-hal yang diwajibkan Allah swt., kepada mereka dan apa yang dilarang-Nya.

Usaha yang dilakukan untuk menjaga dari kehancuran dapat diperoleh dengan cara memberikan bimbingan perkawinan sebelum mamasuki jenjang perkawinan. Dalam menwujudkan hal tersebut melalui kursus calon pengantin. Selain itu juga terdapat dalam QS al- al-Așr/103:3, firman Allah swt :

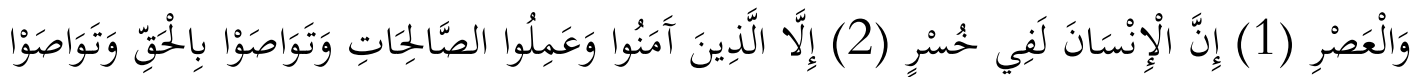

$$
\begin{aligned}
& \text { بِالصَّنَّْ (3) }
\end{aligned}
$$

Terjemahnya: h. 561 .

${ }^{10}$ Kementrian Agama RI, Al-Qur'an dan Terjemahnya. (Bogor:PT.PantjaCemerlang, 2014), 


\section{Proses Pelaksanaan Kursus Calon Pengantin di Kantor Urusan Agama Kecamatan Tamalanrea...}

"Kecuali orang-orang yang beriman dan mengerjakan amal saleh dan nasehat menasehati supaya mentaati kebenaran dan nasehat menasehati supaya menetapi kesabaran." $" 11$

Ayat ini memberikan keterangan bahwa Allah swt. yaitu beriman kepada apa yang diperintahkan Allah untuk diimani, dan iman tidak dapat terwujud kecuali dengan ilmu (belajar), sehingga ia merupakan bagian yang menyempurnakannya. Dalam ayat ini terdapat dalil untuk mendahulukan ilmu sebelum beramal. Amal saleh mencakup semua perbuatan yang baik yang tampak maupun yang tersembunyi; yang terkait dengan hak Allah maupun hak manusia, yang wajib maupun yang sunat. Yaitu iman dan amal saleh, yakni saling menasihati untuk melakukan hal itu dan mendorongnya. Yakni bersabar untuk tetap menaati Allah, bersabar untuk tetap menjauhi larangan Allah dan bersabar terhadap taqdir Allah yang pedih. Kedua hal yang sebelumnya, yaitu iman dan amal saleh dapat menyempurnakan diri seseorang, sedangkan kedua hal yang setelahnya dapat menyempurnakan orang lain. Dengan keempat perkara itulah seseorang akan selamat dari kerugian dan memperoleh keberuntungan. Syaikh Muhammad bin 'Abdul Wahhab dalam Al Ushul Ats Tsalaatsah berdalih dengan surah ini untuk menerangkan kewajiban seorang muslim, yaitu ilmu, amal, dakwah dan sabar.

Demikian halnya dengan kursus calon pengantin sesuai dengan fungsinya berupaya untuk memberikan nasehat khususnya yang berhubungan dengan masalah perkawinan dan keluarga yang benar menurut yang disyariatkan oleh Allah swt. dengan nasehat yang baik diharapkan dapat mengantarkan pasangan suami istri menjadi pasangan harmonis.

2) Undang-undang No. 1 pasal 1 Tahun 1974,

Undang-undang No. 1 pasal 1 menyebutkan bahwa pernikahan adalah ikatan lahir batin antara seorang laki-laki dan perempuan sebagai suami istri dengan tujuan membentuk keluarg atau rumah tangga yang bahagia dan kekal berdasarkan ketuhanan Yang Maha Esa.

Undang-undang No. 23 Tahun 2004 tentang penghapusan kekerasan dalam rumah tangga. Keutuhan dan kerukunan rumah tangga yang bahagia, aman, tentram dan damai merupakan dambaan setiap orang. Dengan demikian setiap orang dalam lingkungan ruamah tangga dalam melaksankan hak dan keawajiban harus didasari oleh agama.

Keputusan Menteri Agama Nomor 3 Tahun 1999 tentang Gerakan Keluarga Sakinah. Kriteria keluarga sakinah adalah keluarga yang dibina atas pernikahan yang sah, mampu memenuhi hajat hidup spiritual dan material secara layak dan seimbang, suasana kasih sayang antara anggota keluarga dan lingkunganya dengan selaras dan serasi, serata mengamalkan, menghayati dan memperdalam nilai-nilai keimanan, ketaqwaan dan akhlak mulia.

D. Tujuan Kursus Calon Pengantin

Keluarga sebagai komunitas terkecil dari struktur masyarakat yang memegang peran yang sangat penting dalam mewujudkan masyarakat yang sejahterah. Sebab keluarga diikat oleh beberapa peraturan agama, adat dan tradisi. Apabila keluarga menjadi penopang masyarakat maka pernikahan menjadi dasar yang menetukan posisi sebuah keluarga. Karena itu pemerintah mengeluarkan kebijakan pembinaan untuk mewujudkan keluarga yang berkualitas melalui program kursus calon pengantin.

\footnotetext{
${ }^{11}$ Kementrian Agama RI, Al-Qur'an dan Terjemahnya. h. 602.
} 
Berangkat dari dalil-dalil yang dipaparkan diatas, dapat dipahami tujuan dari bimbingan kursus calon pengantin sebagai berikut:

a. Membantu individu mencegah timbulnya problem yang berkaitan dengan pernikahan yaitu dengan membantu individu memahami tentang hakekat, tujuan, syarat-syarat kesiapan dirinya untuk melaksanakan pernikahan sesuai dengan ketentuan, syariat Islam.

b. Membantu individu mencegah problem-problem yang berkaitan dengan kehidupan rumah tangga, antara lain dengan membantu individu memahami hakekat, tujuan hidup berkeluarga dan cara-cara membina kehidupan berkeluarga yang sakinah, mawaddah, dan rahmah menurut ajaran Islam.

c. Membantu individu mencegah masalah-masalah yang berkaitan dengan pernikahan dan kehidupan berumah tangga antara lain dengan membantu individu memahami problem, memahami kondisi dirinya, keluarga, dan lingkungannya serta membantu individu menetapkan pilihan pemecahan masalah yang dihadapinya sesuai dengan ajaran Islam.

d. Membantu individu memelihara situasi dan kondisi pernikahan dan rumah tangga agar tetap baik dan mengembangkannya agar jauh lebih baik. ${ }^{12}$

\section{METODOLOGI PENELITIAN}

Penelitian ini menggunakan jenis penelitian (field research) kualitatif deskriptif. Lokasi penelitian berada pada dua (2) wilayah kecamatan di Kota Makassar yakni KUA Tamalanrea dan KUA Biringkanaya. Pendekatan penelitian yang digunakan adalah pendekatan teologis (syar'i), pendekatan yuridis formal, dan pendekatan sosiologis. Sumber data yakni Kepala Kantor Urusan Agama dan beberapa Pejabat dan Penyuluh Kantor Urusan Agama di Kecamatan Biringkanya dan Kecamatan Tamalanrea serta beberapa resopnden lainnya. Data dikumpulkan melalui observasi, wawancara, dan dokuementasi dengan instrumen pedoman observasi dan pedoman wawancara. Data diolah dengan reduksi data, penyajian data, dan penarikan kesimpulan.

\section{HASIL PENELITIAN DAN PEMBAHASAN}

\section{Proses Pelaksanaan Suscatin di KUA Kecamatan Tamalanrea}

Hasil penelusuran peneliti dapat menganalisis dari apa yang diperoleh pada Kantor KUA Kecamatan Tamalanrea kota Makassar dengan menggunakan salah satu metode yaitu metode wawancara.

Proses pelakasanaan suscatin di KUA Kecamatan Tamalanrea Makassar apabila merujuk kepada aturan Direktur Jendral Bimbingan Masyarakat Islam Nomor : DJ. II/542 tahun 2013, bahwa kegiatan kursus calon pengantin dimaksudkan bertujuan untuk mewujudkan keluarga yang yang harmonis selain itu, mengurangi potensi timbulnya perselisihan, perceraian, dan kekerasan dalam tangga (KDRT). Kursus calon pengantin ini merupakan salah satu tahapan yang mesti dilakukan sebelum proses akad nikah dilaksanakan, pada proses pelaksanaannya, kursus calon pengantin di Kantor KUA Kecamatan Tamalanrea Kota Makassar setiap peserta menerima materi kursus dari nasumber.

\footnotetext{
${ }^{12}$ Aunurrahim Faqih, Bimbingan dan Konseling Dalam Islam (Yogyakarta: UII Press, 2001), h.
} 


\section{Proses Pelaksanaan Kursus Calon Pengantin di Kantor Urusan Agama Kecamatan Tamalanrea...}

Pasangan calon pengantin yang mendaftarkan diri di KUA Kecamatan Tamalanrea harus mengikuti kursus calon pengantin sebelum akad nikah dilaksanakan sebab kursus ini merukan persyaratan pencatatan nikah, ketika salah seorang calon dari pengantin (khususnya calon pengantin laki-laki) yang bertempat tinggal diluar kecamatan tamalanrea atau daerah harus mengikuti kursus tersebut di KUA daerah tempat tinggalnya karena setelah proses kursus calon pengantin setiap calon mendapatkan sertifikat kursus yang dikeluarkan oleh KUA yang menjadi berkas kelengkapan pencatatn nikah di KUA Kecamatan Tamalanrea.

Penyelenggara kursus calon pengantin di KUA Kecamatan Tamalanrea adalah penghulu dan penyuluh yang bekerja sama dengan BP4 yang jadwal pelaksanaan kursus pada umumnya di laksanakan pada hari selasa mulai dari jam 08.00 sampai dengan jam 12.00 yaitu hanya sekitar 3 sampai 4 jam bimbingan dalam sehari, bagi pasangan calon pengantin yang tidak sempat mengikuti kursus calon penganti wajib mengikuti dihari lain, karena tanggung jawab yang dimiliki oleh pihak KUA siap melayani sebagai penyelenggara kursus calon pengantin dapat dilaksanakan selama jam kerja dan setiap calon yang telah mengikuti kursus calon pengantin diberikan sertifikat sebagai bukti pernah mengikuti kusus tersebut.

Pelaksanaan bimbingan kursus calon pengantin dalam menyampaikan materi, narasumber menggunanakan metode model penasehatan ceramah, pola tanya jawab, sehingga calon penggantin lebih mudah memahami dan telah memiliki gambaran mengenai permasalahan-permasalah yang akan muncul ketika berumah tangga dan solusi penyelesaian masalah dalam rumah tangga dengan bijak. Menurut Kepala KUA Kecamatan Tamalanrea mengatakan "pelaksanaan kursus calon pengantin itu sangat penting, karena kita sangat perlu mendeteksi calon pengantin bahwa pernikahan bukan hanya sekedar mampu menikah saja dan bukan hanya menilai pernikahan itu sebagai ibadah dan melanjutkan keturunan, melainkan sangat perlu bagi kita pahami kursus calon pengantin ini dapat dijadikan landasan atau bekal pengetahuan bagi mereka dan manfaatnya itu sangat penting untuk calon pengantin" 13

Senada dengan penghulu KUA Kecamatan Tamalanrea mengatakan "dalam penyampian materi dengan model ceramah atau diskusi, penyampaian materi dengan cara berpasangan ataupun berkelompok sesuai dengan volume pendaftar yang telah ditentukan dan yang hadir pada hari itu, sebelum penyampain materi, narasumber melakukan wawancara kepada setiap peserta dengan tujuan mengetahui latar belakang para peserta kursus calon pengantin, sehingga narasumber mampu mengukur kemampuan-kemampuan pengetahuan dasar tentang sebuah pernikahan yang diketahui oleh peserta sehingga narasumber bisa memilih materi apa yang mesti disampaikan dan memilih metode model ceramah yang lebih mudah dipahami oleh peserta kursus calon pengantin. $^{14}$

Materi yang disampaikan dalam proses pelaksanaan kursus calon pengantin di KUA Kecamatan Tamalanrea Kota Makassar, sebagai berikut:

1. Kemampuan baca tulis Al-Qur'an

2. Pengetahuan Agama

\section{Nopember 2018}

${ }^{13}$ Abd. Wahab, Kepala KUA Kecamatan Tamalanrea Kota Makassar, Wawancara pada tanggal

${ }^{14}$ Musliadi, Penghulu KUA Kecamatan Tamalanrea Kota Makassar, Wawancara pada tanggal 6 Nopember 2018 
1) Rukun Islam

2) Rukun Iman

3) Taharah (bersuci)

4) Ibadah

3. Pengetahuan Munakahät

1) Tujuan perkawinan

2) Rukun dan syarat

3) Hak dan Kewajiban Suami Istri

4) Penyaluran Seks Suami-Istri

5) Putusnya perkawinan

6) Pembinaan keluarga sakinah

Proses Pelakasanaan dan realisasi kursus calon pengantin di KUA Kecamatan Tamalanra baik itu durasi jam kursus dan meteri-materi yang disampaikan sudah berjalan dengan baik meskipun dalam proses pelakasanaan kursus calon pengantin ketika mengacu pada perat uran Direktorat Jendral bimbingan Masyarakat Islam Nomor : DJ.II/542 Tahun 2013 masih belum efektif.

\section{Proses pelaksanaan di KUA Kecamatan Biringkanaya}

Berdasarkan ketentuan pasal 4 ayat (1) Peraturan Direktur Jenderal Masyarakat Islam Tahun 2011 tentang Kursus calon pengantin bahwa penyelenggara Kursus Pranikah adalah Badan Penasihatan, Pembinaan, dan Pelestarian Perkawinan (BP4) atau lembaga lainnya sebagai penyelenggara kursus calon pengantin yang telah mendapat Akreditasi dari Kementerian Agama. Pejabat dari BP4 itu sendiri adalah Kepala KUA sehingga yang bertanggung jawab penuh terhadap pelaksanaan kursus calon pengantin adalah pejabat Kantor Urusan Agama pada kecamatan di kota makassar.

Berdasarkan hal tersebut, pelaksanaan kursus calon pengantin pun dilaksanakan di kantor urusan agama, yaitu paling lambat sepuluh hari sebelum pelaksanaan ijabqabul ketika calon pengantin datang ke KUA untuk mendaftar dengan membawa berkas-berkas atau kelengkapan administrasi untuk menikah. Apabila syarat-syarat administrasinya telah terpenuhi, mereka pun kemudian didaftar lalu melakukan pembayaran di bank tertentu yang telah ditunjuk oleh pemerintah. Setelah itu, kedua calon mempelai diberi pembinaan atau juga bisa disebut kursus calon pengantin, istilah kursus calon pengantin untuk semua calon pengantin yang datang ke KUA untuk mendaftarkan perkawinannya diwajibkan mengikuti kursus tersebut sebagai syarat menikah. $^{15}$

Kursus calon pengantin tersebut, mereka diberikan penjelasan dan pengarahan seputar masalah pernikahan dan kehidupan rumah tangga. Durasi waktu pembinaan kursus pranikah tersebut ialah 30-60 menit, berbeda dengan durasi waktu yang ditetapkan dalam silabus mata diklat Program Kursus yang diterbitkan oleh Direktur Jenderal Bimbingan Masyarakat Islam tahun 2013 yaitu berjumlah 16 jam. Pada 15 menit pertama, pemberi materi memberikan pengantar tentang tujuan pernikahan, thaharah dan ibadah. Setelah itu, narasumber memberikan kesempatan kepada peserta untuk bertanya. Setelah itu, materi dilanjutkan kembali dengan uraian tentang hak-hak 2018.

\footnotetext{
${ }^{15}$ Andi Irwan Kepala KUA Kecamatan Biringkanaya, wawancara oleh penulis, 2 November
} 


\section{Proses Pelaksanaan Kursus Calon Pengantin di Kantor Urusan Agama Kecamatan Tamalanrea...}

dan kewajiban suami-isteri, bagaimana menciptakan keluarga yang harmonis, dan bagaimana mengantisispasi percekcokan dalam rumah tangga sekaligus pemberian nasehat bagaimana menyelesaikan permasalahan dalam membina rumah tangga.

Menurut penghulu KUA Kecamatan Biringkanaya bahwa Pendekatan dalam pembinaan yang dilakukan KUA ini disebut top down yang artinya pendekatan program yang dilakukan didesain oleh KUA tanpa melihat latar belakang calon pengantin. Inisiatif ini diambil dari kebijakan kepala kantor urusan Agama. Kalau pada saat itu calon pengantinnya banyak, maka dilakukan pembinaan secara berkelompok. ${ }^{16}$

Waktu pelaksanaan Kursus calon penganti yang dilakukan oleh KUA Kecamatan Biringkanaya sekali dalam seminggu yaitu setiap hari rabu mulai dari pukul 09.00 Wita S/d 11.00 Wita, kurang lebih sepuluh hari sebelum pelaksanaan akad nikah, tetapi jika terdapat satu pasangan maka waktu pelaksanaan kursus calon pengantin disesuaikan selama jam kerja. Setelah kedua calon pengantin telah menyelesaikan biaya administrasi nikah di bank yang telah ditentukan.

Materi-materi yang disajikan pada saat kersus calon pengantin yang diberikan di Kantor Urusan Agama Kacamatan Biringkanaya mengenai ilmu-ilmu fiqih tentang thaharah, nasehat-nasehat perkawinan meliputi cara melestarikan perkawinan, saling menjaga keharmonisan keluarga dan solusi mengatasi konflik.

Metode yang digunakan dalam menyampaikan materi yaitu ceramah dan tanya jawab. Sementara dalam pedoman penyelenggaraan kursus calon pengantin yang ditetapkan dalam penyampaian materi selain ceramah dan tanya jawab, juga berupa simulasi (studi kasus) dan penugasan. Metode-metode ini digunakan menyesuaikan dengan materi yang telah ditentukan tanpa kondisi yang latar pendidikan yang berbeda-beda, banyak calon pengantin yang sama-sama bekerja, dan calon pengantin tempat tinggalnya berjauhan.

Kemudian itu, materi yang disampaikan adalah meteri yang dibuat oleh pemateri atau pejabat KUA dengan materi berdasarkan kondisi masyarakat dan pengalaman yang sering dihadapi di daerah tersebut. Kurangnya waktu dalam penyampaian materi serta banyaknya meteri dalam silabus diklat yang diterbitkan oleh Direktur Jenderal Bimbingan Masyarakat Islam tahun 2013 tidak memungkinkan peserta kursus calon pengantin untuk menerima semua materi sehingga yang menjadi pertimbangan para pelaksana kursus calon pengantin membuat rangkuman materi yang dianggap paling penting untuk diketahui dan dipahami serta diamalkan oleh para calon pengantin sebagai bahan bekal dalam berumah tangga dengan waktu yang lebih singkat.

Penyelenggaraan kursus calon pengantin idealnya menghadirkan beberapa orang narasumber atau pemateri, mengingat banyaknya jumlah materi yang semestinya disampaikan dalam kursus calon pengantin tersebut, sedangkan pemateri dituntut dari orang yang ahli dibidangnya. Sementara untuk membawakan materi pada kursus calon pengantin kecil kemungkinan satu orang dapat menguasai seluruhan materi sucatin. Namun pada kenyataannya realisasi pelaksanaan kursus calon pengantin pada Kantor Urusan Agama di Kecamatan Biringkanaya dan Kecamatan Tamalanrea umumnya hanya dibawakan oleh satu orang dalam setiap pelaksanaannya. Kenyataan tersebut

\footnotetext{
${ }^{16}$ Abd. Rauf, Penghulu KUA Kecamatan Biringkanaya, wawancara oleh penulis, 2 November 2018.
} 
menyebabkan pelaksanaan Suscatin diselenggarakan dengan cara sangat sederhana dimana dalam melaksanakan pembimbingan, satu orang pemateri atau narasumber bertanggung jawab penuh terhadap aktifitas kursus calon pengantin yang dilaksanakan dengan cara mengelompokkan beberapa pasangan calon pengantin dalam satu kali pelaksanaan.

\section{PENUTUP}

Berdasarkan paparan hasil penelitian di atas, maka dapat disimpulkan bahwa proses penyelenggaraan kursus calon pengantin pada Kantor Urusan Agama Kecamatan Tamalanrea dan Biringkanaya Kota Makassar masih jauh dari target waktu yang diharapkan yaitu sekurang-kurangnya 16 jam pelajaran, semetara realisasinya hanya berkisar kurang lebih 2 jam, sehingga berpengaruh terhadap target materi yang ingin disampaikan. Dengan demikian proses pelaksanaan suscatin pada Kantor Urusan Agama di Kecamatan Tamaranrea dan Kecamatan Biringkanaya Kota Makassar terkesan hanya menjalankan peraturan tetapi mengabaikan apa yang sebenarnya yang menjadi esensi dari pelaksanaan suscatin tersebut. Suscatin atau bimbingan yang diberikan kepada calon pengantin merupakan dasar dari tujuan membangun keluarga yang harmonis.

\section{DAFTAR PUSTAKA}

Faqih, Aunurrahim, Bimbingan dan Konseling dalam Islam Yogyakarta: UII Press, 2001.

Gito, Bimo Wal, Bimbingan dan Konseling Perkawinan, Yogyakarta: Yayasan Penerbit Fakultas Psikologi UGM, 1984.

Hamid, Rosmaniah, Hadis-Hadis Keluarga dan Sakinah dan Implementasinya dalam Pembentukan Masyarakat Madani Cet, I; Makassar: Alauddin University Press, 2011 .

Kementerian Agama RI, Direktorat Jenderal Bimbingan Masyarakat Islam, Pedoman Penyelenggaraan Kursus Pra Nikah Jakarta: Kementerian Agama RI, 2011.

, Direktorat Jenderal Bimbingan Masyarakat Islam, Pedoman Penyelenggaraan Kursus Pra Nikah, Jakarta: Kementerian Agama RI, 2013

, Direktorat Jenderal Bimbingan Masyarakat Islam, Modul Pelatihan Motivator Keluarga Sakinah, Jakarta: Kementerian Agama RI, 2011. , Al-Qur'an dan Terjemahnya, Bogor:PT.PantjaCemerlang, 2014.

Ridwan, Muhammad Saleh, Keluarga Sakinah Mawadda Warahma Cet, I; Makassar: Alauddin University Press, 2012.

Syahraeni, Andi, Bimbingan Keluarga Sakinah, Cet, I; Makassar: Alauddin University Press, 2013.

\section{Sumber Wawancara}


Abd. Wahab, Kepala KUA Kecamatan Tamalanrea Kota Makassar

Musliadi, Penghulu KUA Kecamatan Tamalanrea Kota Makassar

Andi Irwan Kepala KUA Kecamatan Biringkanaya

Abd. Rauf, Penghulu KUA Kecamatan Biringkanaya 